\title{
THE USE OF PUBLIC RELATIONS IN PROJECTING AN ORGANIZATION'S POSITIVE IMAGE
}

\author{
Ioana Olariu \\ „Vasile Alecsandri” University of Bacău, Faculty of Economic Sciences \\ ioana_barin_olariu@yahoo.com
}

\begin{abstract}
This article is a theoretical approach on the importance of using public relations in helping an organization to project a positive image. The study of the impact information has on the image of organisations seems to be an interesting research topic. Practice has proved that the image of institutions has a patrimonial value and it is sometimes essential in raising their credibility. It can be said that an image is defined as the representation of certain attitudes, opinions or prejudices concerning a person, a group of persons or the public opinion concerning an institution. In other words, an image is the opinion of a person, of a group of persons or of the public opinion regarding that institution. All specialists agree that a negative image affects, sometimes to an incredible extent, the success of an institution. In the contemporary age, we cannot speak about public opinion without taking into consideration the mass media as a main agent in transmitting the information to the public, with unlimited possibilities of influencing or forming it. The plan for the PR department starts with its own declaration of principles, which describes its roles and contribution to the organisation.
\end{abstract}

\section{Keywords}

communication instrument; corporate identity; credibility; mass media; organization image; promotion; public relations

\section{JEL Classification}

M41

\section{Introduction}

Public relations represents an important promotion and communication instrument. Although it is less often used, it has a significant potential in raising public awareness and creating preference for a certain product on the market, as well as in repositioning and maintaining products on the market. The main instruments of public relations are publications, demonstrations, news, discourses, activities for public service, written or audio-visual materials, means of constructing corporate identity and telephone services. The planning of public relations activities involves establishing public relations objectives, choosing the appropriate messages and means to transmit them, as well as evaluating the results.

A major mass promotion instrument is represented by the activity of public relations creating good relations with various existing categories of the public, obtaining a favourable media representation, creating a company image in the public perception, and judiciously managing or removing the negative effects of rumours, accounts or unfavourable events that are harmful to the firm. The Public Relations Department can partly or entirely fulfil any of the following functions:

Maintaining relations with the press or mediating these relations: creating and placing in the press valuable information deemed as newsworthy in order to attract the attention toward a person, product or service.

Propaganda in favour of products: using public communication tools in order to popularize a firm's products.

Public business: building and cultivating relations with the national or local community. 
Lobbying activities: creating and maintaining relations with lawmakers and governmental officials in order to influence legislation and regulations.

Relations with investors: maintaining relations with shareholders and other categories of persons from the financial community who are equally interested in the organisation. Promoting public development: public relations with donators or members of nonprofit organisations in order to obtain financial support of support in the form of voluntary work.

The public relations activity is used for promoting a variety of things/matters: products, people, places, ideas, activities, organisations and even countries. Companies resort to public relations activities in order to build good relations with the consumers, investors, mass communication means and with the communities where they operate.

\section{The role and impact of public relations}

Public relations can have a powerful impact on the public conscience, at a cost price which is far lower than commercial publicity could achieve by means of commercials. If the company can come up with some interesting information, it will be taken over by numerous and varied press means, the effect being the same as that obtained when opting for promotion. The results generated by the intelligent management of the public relations activity can sometimes be spectacular.

\section{Major public relations tools}

Specialists in public relations make use of more specific instruments, among which news constitutes a very important tool. Public relations professionals find or even create favourable news about a firm and its products or people. Sometimes, news topics occur naturally; some other times, the specialist in public relations can suggest events or activities that are liable to create such a subject. Public discourses can also generate mediatisation for the firm. It has become increasingly common for leaders of companies to answer questions addressed by journalists or to speak during meetings organised by owners' associations or during sales conferences, while these events can strengthen the firm's image. Another instrument which is specific to public relations is represented by special events: starting with press conferences, visits to spaces where the company operates organised for journalists, inaugurations and fireworks, and ending with laser light shows, hot air balloon launches, multimedia presentations, spectacular manifestations featuring celebrities or educational programmes aimed at reaching certain targeted public groups and raising their interest. Mobile marketing - in the form of promotional tours that bring the trademark right in front of the consumer - has become an efficient means of building individualised relationships with targeted consumers.

Public relations specialists also elaborate written materials aimed at approaching and influencing the targeted markets, among which we find: annual activity reports, brochures, articles, informative bulletins and magazines/publications edited by the company. Audio-visual materials such as films, presentations, audio and video CDs are equally used as communicational instruments. Corporate identity materials can also help in creating a company identity which is immediately recognizable by the public. Logos, headers, brochures, inscriptions, standardized forms, business cards, buildings, uniforms and cars that belong to the firm - all of them become marketing instruments when they are appealing, distinctive and memorable. Finally, firms can attract the public's goodwill by contributing financially and with voluntary effort to activities for public service. A firm's site can also be a good way of maintaining public relations. Consumers and other categories of the public can access the website for information as well as for entertaining activities, as such sites are enjoying significant popularity. Websites can also be ideal instruments for managing situations of crisis. 
Just as in the case of the other promotion tools, by analysing when and how to use public relations for the promotion of a product, the managerial board must establish the objectives of the public relations activity, must choose the public relations messages and the means by which these messages are to be communicated, must implement the public relations plan and it must also evaluate the results. The public relations of a company must be harmonized with all other promotion activities, as a part of the comprehensive effort of integrated marketing communications.

Public relations involves various programmes destined for the promotion or protection of a firm's image or of its products on the market.

The influence exercised by public relations is based on its distinct characteristics:

High credibility level: news and reports seem to be more authentic and more credible than commercials.

Lack of consumer reluctance: public relations can establish contacts with potential clients who might avoid sales agents and publicity. The message reaches the consumers more likely as a piece of news rather than as a type of communication regarding sales. Presentation: public relations, just like publicity, can make the presentation of a firm or product.

The public relations activity can contribute to the accomplishment of the following tasks:

- It gives assistance when new products are launched on the market;

- It gives assistance during actions of repositioning on the market products that have reached their maturity stage;

- It contributes to raising interest in a certain category of products;

- It contributes to influencing certain target groups;

- It defends the products that have faced problems from the public;

- It creates a company image in a way which positively affects its products.

\section{Main decisions made in public relations}

Establishing marketing objectives

Public relations can contribute to accomplishing the following objectives:

- Informing the public;

- Strengthening credibility;

- Stimulating the sales force and the distributors;

- Maintaining promotional expenses as a low level.

Choosing messages and PR means

In the next stage, the public relations specialist identifies or elaborates interesting news concerning a product.

\section{Implementing the public relations plan}

Evaluating results

The contribution of public relations is difficult to measure because other promotional tools are used in parallel. If public relations are used before the other instruments then its contribution can be assessed more easily.

Expositions: the easiest manner of measuring the efficiency of public relations activities is by determining the number of presentations delivered as a part of information means.

Raising awareness/acquiring knowledge/determining attitudinal changes: a good measurement method is the study of changes occurring in consumers' awareness/knowledge/attitude toward the product as a consequence of the public relations campaign.

Contribution to sales and profit: the impact on sales and profit represents the most satisfying indicator, in case it can be obtained. 


\section{Planning and managing public relations activities}

The role of public relations in the formal planning of an organisation is significant. Public relations counsellors help in creating a declaration of organisational principles thus offering useful advice regarding the public and advice on strategies of accomplishing objectives, as well as on monitoring the organisation's environment as a part of establishing the objectives and goals of the organisation available for a year, for five years or for ten years. Additionally, the PR department should establish its own objectives and communication goals. Some PR communication plans are directly related to the organisation's plans. Even if an organisation does not have plans established for certain periods, the PR department should nevertheless have a general communication plan that fits the annual activities of the organisation. Moreover, the PR department needs a communication plan in the case of crises, or at least some general rules for crisis management.

\section{The image of organisations}

\section{Managing organisations' image}

The creation of an organisation's image can be realized by applying a certain policy which depends on the managerial style of the organisation's leader, one the one hand, and on the activity of the employees, on the other hand. This policy is translated in practice by a series of public relations activities that are temporally arranged and which have the aim of forming, changing or maintaining an institution's image. These are:

Developing a high-performance management at the level of the institution.

The range of activities leading to the success of the organisation depends on its management, but what is nevertheless essential in order to form, change or maintain its image is to carry out a high-performance activity.

Developing, at the level of the organisation, a strategy of gaining the trust and the sympathies of the company's own employees.

It is a public relations strategy involving the inculcation of the personnel with the institution's philosophy, in which the central element is understanding its mission. It is important that each employee consider himself/herself as a co-participant in the organisation's activity and the institution thus appears in their mind as being the one which allows them to fully exercise their inventive or creative spirit and, ultimately, their personality. The activity as such is hard to achieve and entails investing time, patience and passion from the managers' part, as well as understanding and patience from the part of the employees.

Running a sustained promotional campaign and, in certain conditions, even an aggressive one. The informative activity must be performed regularly, according to a certain schedule, or periodically, during different shows in the mass media that rank highest in the public's taste.

Making recourse to sponsorship.

In the public relations activity, sponsoring is one of the commonest methods employed for the creation of a correct and real image of institutions.

The first refers to Coca-Cola, who has been sponsoring the main sports events of the planet for several years (the Olympic Games, the World Cup, etc.) and seeking to give its products an image that is associated with youth, health, with the desire to be the best. The company builds its image on the mosaic principle and the sponsorship of the main sporting events is just a sequence of its public relations activity. The second concerns the eternal rival of Coca-Cola, Pepsi-Cola, fear of the unusual impact of sponsoring major cultural and artistic events, and especially known rock and pop music bands. The effect was immediately seen, the image of the company was associated with modernism and youth. The third example relates to the Marlboro brand, which managed its image by sponsoring in particular Formula 1 motor racing, and managed to create an image 
associated with youth and courage. The three examples reinforce the idea that sponsorship is a very effective way to manage an organization's image.

Hiring a very well-trained personnel who behave decently and eliminating those that commit acts of deviation or misbehave.

Organisations' personnel have an essential role in promoting a trademark image. It can be said that the good functioning of the company and its success largely depend on the quality of the personnel. Irrespective of the nature of the company's activity, the hiring of new members should necessarily take into consideration, among others, the following aspects: the candidate's temperament; personality features; attitude, aptitudes and psychic abilities; interests, aspirations, wishes; political beliefs; level of professional training; experience for the targeted position; medical condition; extraprofessional activities performed; behaviour in the family and in society; family condition; reasons for seeking employment. All these requirements that a candidate should meet in order to be hired have as a purpose the taking in of people who are welltrained, serious and stimulated by the wish to accomplish their professional goals.

Maintaining very good relations with the mass media. This is an indispensable condition for success.

\section{Conclusions}

The major objective of the public relations activity is that of instituting, among a significant part of the public, a climate of trust in the firm, in its capacity of satisfying the needs and requirements of various consumer and user categories. It is typical of this type of activity to focus increasingly on promoting relations with physical and legal persons, to seek to inspire trust and understanding, to address the public opinion by means of the various categories of the public, to have an activity that has a double direction - toward the public and coming from the public, or to try to win the potential consumers' sympathy or attachment. There is an unlimited number of events economic, scientific, cultural, sports - that an enterprise can create and use to its own interest, for highlighting its offer, or for consolidating its own image. It should be added that by means of various forms and specific techniques the public relations activity contributes to the accomplishment of the firm's various targets, among which we can mention: boosting consumers' trust in the company's offer; launching new products on the market; revitalizing, repositioning and re-launching products on the market; creating or maintaining the consumers'/users' interest in a category of products or services; consolidating the company's position on various markets; extending the strength of publicity and of various forms of promotion; informing consumers on extending the possibilities of using its products/services; bringing additions to publicity messages; informing, influencing and attracting opinion leaders; bringing additions to and strengthening sales promotions campaigns; forming the enterprise image; raising the company's prestige and improving its offer by attracting sponsors in promotional activities; differentiating the company's offer from that of its competitors; stimulating the demand for goods and services.

No matter what means and techniques are used, the public relations activity must be correlated with the other promotional variables, integrated in a unitary programme, with a global vision. At the same time, it should be taken into consideration that the efficiency of public relations activities largely depends on the qualitative level of the overall activity of the enterprise.

\section{References}

Cutlip, S., Center, A., Broom, G. (2000), Effective public relations, ediția a 8-a, Upper Saddle River, NJ; 
Gregory, A. (2009), Planificarea și managementul campaniilor de relații publice, Editura Polirom, Iași;

Kotler, Ph., Armstrong, G. (2008), Principiile marketingului, Editura Brandbuilders, București;

Myers, J.H., (1986), Marketing, McGraw-Hill, Inc.;

Newsom, D., VanSlyke, T., Kruckeberg, D. (2003), Totul despre relațiile publice, Editura Polirom, Iași;

Saffir, L. (2008), PR cu buget restrâns, Editura Uranus, București;

Stancu, V., Stoica, M., Stoica, A. (1998), Relații publice, succes și credibilitate, Editura Concept, București;

Șerbu, S. (2007), Relații publice și comunicare, Editura Teora, Bucureşti;

Toffler, A. (1995), Puterea în mișcare, Editura Antet, Oradea. 